\title{
School principal strategies in improving the competitiveness
}

\author{
Sri Kuryani ${ }^{1}$,Yasir Arafat ${ }^{2}$, Mulyadi Mulyadi ${ }^{2}$ \\ ${ }^{1}$ Sekolah Dasar Negeri 2 Tanjung Kerang, Indonesia \\ ${ }^{2}$ Universitas PGRI Palembang, Indonesia
}

\section{Article Info}

\section{Article history:}

Received Jun $22^{\text {th }}, 2021$

Revised Aug 13 ${ }^{\mathrm{h}}, 2021$

Accepted Aug 30 ${ }^{\text {th }}, 2021$

\section{Keyword:}

Principal, Strategy, School Competitiveness

\begin{abstract}
This study aimed to determine and analyze knowing and describing the principal's strategy in increasing the competitiveness of SD Negeri 1 Supat, Babat Supat District. This type of research was descriptive qualitative research. Data collection tools used were documentation, interviews, observation and literature review. The data analysis technique used was descriptive qualitative analysis technique which consisted of data collection, data reduction, data presentation, and drawing conclusions and fermentation. The results of the study stated that 1) the principal's strategy in increasing competitiveness at SD Negeri 1 Supat, Babat Supat District a) planning a program to improve the quality and competitiveness of the school both in the short and long term; b) determine the program that has been planned in the form of an activity instrument which is carried out in SD Negeri 1 Supat, Babat Supat District; and c) implement the strategy set by the school; 2) The obstacles faced in efforts to increase competitiveness lie in efforts to improve the quality of learning at SD Negeri 1 Supat; and 3) Solutions to some of the obstacles faced in increasing competitiveness through the quality of learning at SD Negeri 1 Supat, among others by: a) implementing continuous coaching to increase the experience and knowledge of teachers; b) supervise teachers as well as evaluate and provide direction for improvement. Provide training and assignments to improve teacher skills; c) assignments in various activities both at school and outside of school and provide opportunities for teachers to interact and communicate with many parties; and d) capacity building activities carried out through sending training participants, workshops, socialization, training, and KKG activities.
\end{abstract}

(C) 2021 The Authors. Published by IICET

This is an open access article under the CC BY-NC-SA license (https://creativecommons.org/licenses/by-nc$\mathrm{sa} / 4.0$

\section{Corresponding Author:}

Kuryani, S.,

Sekolah Dasar Negeri 2 Tanjung Kerang, Indonesia

Email: srikuryani11@gmail.com

\section{Introduction}

Quality education will be obtained at quality schools, and quality schools will produce quality human resources. As the results of research [1] 1) between educational development and economic development there 
is a reciprocal relationship. The higher the education level of the population, the higher the level of economic growth of a country; 2) education and training provide socio-economic benefits to individuals in the form of improvements in income and productivity. For that purpose, the development of education and training is a function of a country's economic growth.

Thus, the demand for quality improvement is a school need that cannot be negotiated because along with the demands of an autonomous environment that has an impact on increasingly competitive school conditions, community needs and learning technology. In an environmental situation full of these dynamics, educational strategic management must be able to create an organization that can provide satisfying services to the community in general and educational objects (students and parents) in particular [2].

Therefore, to build quality and competitive education, a strategy is needed as a long-term organizational plan with regard to how the organization aligns its internal strengths and weaknesses with external opportunities and threats to maintain competitive advantage. The right strategy can lead an organization or educational institution to the success of achieving its goals and still have a competitive advantage [3]. The strategy for increasing the competitiveness of education in schools in its implementation cannot be separated from the strategic management of the principal in improving school quality. As a result of research conducted by [4] which stated that strategic management has a positive effect on school competitiveness.

In this regard, [5] stated that quality improvement management contains efforts to: 1) control the processes that take place in schools both curricular and administrative, 2) involve the diagnostic process, and 3) require the participation of all parties, principals, teachers, staff administration, participants, students, parents and experts. Furthermore, [5] stated that quality improvement management has the principle of: 1) quality improvement must be implemented in schools; 2) quality improvement can be carried out with good leadership; 3) quality improvement must be based on data and facts, both qualitative and quantitative in nature; 4) quality improvement must empower and involve all elements in schools; and 5) quality improvement has the aim that schools can provide satisfaction to students, parents and society.

Thus, a good strategy will assist organizations in allocating their resources in a unique form based on internal competencies and the ability to anticipate the environment. Strategy can be defined as a method or technique applied by a leader, in this case, to achieve the desired goals. Strategy is a leader's tips to achieve goals. To increase the competitiveness of schools, there are several strategies undertaken by the principal, among others, namely, increasing the competence of educators and educational staff. In order to increase the competitiveness of a school, it must be targeted strategies that must be carried out by the principal, because the strategies is a big plan that is increasing, efficient, and productive in order to effectively achieve goals.

The principal as the leader of an educational institution has a very important role in determining what strategies will be taken so that the school being led can attract parents to send their children to the school. Therefore, principals are required to have the ability to plan mature strategies, especially in an effort to improve the competitiveness of the schools they lead.

Supported by the results of [6] which states that: 1) the principal is required to have the ability to transform ideas and imagination and great desires into reality, 2) the school is quality or does not depend heavily on the leadership pattern of the principal, because he is the leader the highest in school and he is the one who can make decisions in everything; 3 ) the role of the principal in improving the quality of education, which includes being an educator, manager, administrator, supervisor, leader, innovator, and motivator; 4) the role is very complex, so the principal must really monitor and evaluate the vision and mission and the programs implemented so that they are able to formulate and analyze for the next programs to be maximized; 5) the concept of quality education is not solely focused on providing educational input factors, but rather pays attention to factors in the educational process.

Thus, the principal, through his central role in educational institutions, can do his best to win the competition, especially through the quality of educational services. Because to win the competition, education providers must have the spirit to always be in front of change with the guarantee that they will get to the finish line first, because competition is a fast race to reach the finish line [7].

This research was conducted at SD Negeri 1 Supat, Babat Supat District as the research site because SD Negeri 1 Supat, Babat Supat District was one of the superior state elementary schools. The excellence of SD Negeri 1 Supat, Babat Supat District could be seen from the achievements both school and student achievements both locally and nationally.Then, SD Negeri 1 Supat, Babat Supat District had competent educator and non-educator resources and facilities and infrastructure. which was adequate and the school location was strategic and easy to reach. Seeing this condition, the researchers decided to carry out research at SD Negeri 1 Supat, Babat Supat District. 
From the results of preliminary observations made by researchers on March 10, 2020 at SD Negeri 1 Supat, Babat Supat District, the researchers stated several indicators stated that the principal had implemented programs that supported improving the competitiveness of SD Negeri 1 Supat, Babat Supat District. Efforts to increase competitiveness carried out by the principal of SD Negeri 1 Babat Supat were formulated through a strategic plan that focuses on improving student academic and non-academic achievement, developing an innovative 2013 curriculum, improving the IT skills of educators and teaching staff and maximizing the use of school facilities and infrastructure.

Some of the researchers' initial findings related to school competitiveness could be seen from the ability of SD Negeri 1 Supat teachers who had participated in the continuous training program, had been able to carry out their duties and responsibilities as educators well. Where the teachers of SD Negeri 1 Supat were not only able to carry out an innovative learning process, both in using various learning media and learning methods and attracting students' interest when carrying out the teaching and learning process.

In other respects, the researchers saw that SD Negeri 1 Supat also carried out an extracurricular activity program which was formulated through the school's vision. Extracurricular activities such as tutoring, scouting, and other activities were images that make the school's reputation increase. This reputation was also supported by the academic and non-academic achievements that had been achieved by students to make SD Negeri 1 Supat the competitive edge. In addition, from the results of preliminary observations made by researchers at SD Negeri 1 Supat, the researchers considered that SD Negeri 1 Supat was supported by adequate educational resources. This could be seen from the good competency of SD Negeri 1 Supat teachers as well as adequate facilities and infrastructure. According to the researcher, this was very supportive of the principal's efforts in increasing school competitiveness. The results of this observation stated that as the most important school competitiveness, the quality of SD Negeri 1 Supat, Babat Supat District was good.

The results of the preliminary observations above, are supported by the results of [8] stated that 1) the principal's strategy in making innovation at SMA N 5 Gorontalo was included in the Medium Competitiveness category; 2) The principal's strategy in implementing teacher development in SMA 5 Gorontalo was included in the moderate competitiveness category; 3) The principal's strategy in developing the Quality of Learning was included in the Medium Competitiveness category; 4) The principal's strategy in conducting school cooperation at SMA N 5 was included in the Medium Competitiveness category. Researchers' suggestions were: 1) The principal was expected to work with all school members; 2) Teachers were expected to improve their performance and professionalism in implementing learning; 3) Administrative staff were expected to further enhance cooperation and responsibility in implementing school programs; 4) Researchers were expected to be able to expand the study of principal leadership strategies.

Then the results of research [9] showed that there were seven strategies used by Islamic school principals to increase school competitiveness. The seven strategies were the effectiveness of the role of the Islamic school committee, restructuring the school organization, developing the education curriculum (KTSP), improving the profession, facilities and infrastructure for educators, implementing various learning programs, and providing additional hours for tutoring lessons. Meanwhile, the accuracy of strategic objectivity to increase competitiveness shows that six sources that have high carrying capacity had proven successful, namely efforts to improve teacher and employee professionalism, improve school management and administration with teamwork, strong and visionary leadership and a solid team, availability. learning resources, improving curriculum implementation, increasing the availability and maintenance of school infrastructure and increasing school accountability.

However, the initial findings of these researchers could not be used as a scientific basis and have not yet been able to describe the principal's strategy in increasing school competitiveness. Therefore, researchers felt it was important to examine more deeply the title of the principal's strategy in an effort to increase the competitiveness of SD Negeri 1 Supat Babat Supat District.

\section{Method}

The approach used in this study was a qualitative method with a descriptive design, namely research that provides an accurate description of a particular individual or group about the conditions and symptoms that occur [10] Researchers focused on the principal's strategy to improve the competitiveness of SD Negeri 1 Supat, Babat Supat District. The principal strategy that was the focus of research includes strategic management of school principals based on a SWOT analysis and increasing school competitiveness.

Data collection techniques used in this study were observation techniques, interviews and documentation studies. The data analysis techniques used included data reduction, data presentation and conclusion drawing. 
The data that had been obtained were processed by using qualitative research, then conducted a domain analysis to obtain a general and comprehensive picture of the object of research through the process of data reduction, display and verification [11] The process of analyzing this data was carried out by researchers continuously. This was done by the researcher in a triangulation manner including observation data, interviews and document studies that were interrelated with one another

\section{Results and Discussions}

\section{The principal's strategy in increasing the competitiveness of SD Negeri 1 Supat, Babat Supat District}

The principal's strategy in increasing the competitiveness of SD Negeri 1 Supat, Babat Supat District, was implemented by means of: 1) planning a program to improve the quality and competitiveness of the school both in the short and long term; 2) determine the program that had been planned in the form of an activity instrument which was carried out at SD Negerio 1 Supat Babat District and 3) Implementing set by the school. The research Result were follow:

1. Planning for Increasing the Competitiveness of SD

Negeri 1 Supat, Babat Supat District. The planning activities to increase the competitiveness of SD Negeri 1 Supat, Babat Supat District, referred to the future reach (vision). Based on the results of data collection conducted by researchers, it can be seen in the following findings

Table $1<$ Planning for Increasing the Competitiveness of SD Negeri 1 Supat, Babat Supat District.

(Results of interviews and documentation from June 2 to August 15, 2020)>

\begin{tabular}{|c|c|c|}
\hline $\begin{array}{l}\text { Research } \\
\text { Focus }\end{array}$ & $\begin{array}{l}\text { Components of } \\
\text { Planning }\end{array}$ & Components of Planning Findings \\
\hline $\begin{array}{l}\text { Planning } \\
\text { for the } \\
\text { principal } \\
\text { of SD } \\
\text { Negeri } 1 \\
\text { Supat, } \\
\text { Babat }\end{array}$ & Collecting data & $\begin{array}{l}\text { 1. The principal conducts an initial analysis to find out what } \\
\text { the school needs in determining the quality improvement } \\
\text { program and school competitiveness } \\
\text { 2. The principal refers to the results of the previous program } \\
\text { evaluation as part of the school needs analysis } \\
\text { 3. The principal conducts a literature review through recent } \\
\text { research studies as a reference for determining school } \\
\text { competitiveness improvement programs }\end{array}$ \\
\hline $\begin{array}{l}\text { Supat sub- } \\
\text { district, } \\
\text { which is }\end{array}$ & Planning a plan & $\begin{array}{l}\text { 1. The planning involved all school stakeholders } \\
\text { 2. The planning involved parents as representatives of the } \\
\text { school committee in providing input }\end{array}$ \\
\hline $\begin{array}{l}\text { vision- } \\
\text { oriented }\end{array}$ & $\begin{array}{l}\text { Implementation of } \\
\text { planning }\end{array}$ & $\begin{array}{l}\text { 1. The principal carries out the planning based on the vision } \\
\text { and mission of the school }\end{array}$ \\
\hline
\end{tabular}

2. Determination of Program for Quality Improvement and impetitiveness of SD Negeri 1 Supat, Babat Supat District Based on the results of data collection carried out by researchers, it can be seen that the determination of the school competitiveness improvement program carried out by the principal referred to the results of the SWOT analysis conducted by the principal of SD Negeri 1 Supat based on the preliminary findings. The results of the analysis of the principal of SD Negeri 1 Supat are as follows:

Table $2<$ The Results of the Analysis of the Principal $>$

\begin{tabular}{|c|c|}
\hline Internal & External \\
\hline Strength $(\mathrm{S})$ & Opportunity $(\mathrm{O})$ \\
\hline $\begin{array}{l}\text { 1. Strategic location, quiet } \\
\text { and comfortable }\end{array}$ & $\begin{array}{l}\text { 1. Local government support related to } \\
\text { School Based Management (SBM) }\end{array}$ \\
\hline 2. Coordination and clear division of tasks & 2. Opportunities to improve competitiveness \\
\hline $\begin{array}{l}\text { 3. The work ethic of } \\
\text { teachers and educators } \\
\text { is high }\end{array}$ & through academic achievement. \\
\hline 4. Teamwork is maintained & \\
\hline $\begin{array}{l}\text { 5. There is a culture of } \\
\text { quality }\end{array}$ & \\
\hline 6. Leadership is firm, and & \\
\hline Experienced & \\
\hline 7. The ability to improve & \\
\hline $\begin{array}{l}\text { the high quality of } \\
\text { learning }\end{array}$ & \\
\hline
\end{tabular}


SO strategy

Using strength to take advantage of opportunities

Weakness (W) / Weakness

1. Incomplete infrastructure

2. Teacher performance improvement programs that are not yet continuous

3. Parents' support has not been maximized

4. The school's financial support as an operational cost for education is not maximized

WO strategy

Correcting weaknesses and taking advantage of opportunities
External
Use force to avoid threats

Threat (Threat)

1. Unstable social, economic and political conditions

Overcoming weaknesses by Avoiding threats

Implementation of Principal Strategies in Efforts to Increase Competitiveness of SD Negeri 1 Supat. Based on the results of data collection conducted by researchers, the following findings can be stated

Table $3<$ Implementation of the Principal's Strategy in an Effort to Improve the Competitiveness of SD Negeri 1 Supat (Results of interviews and documentation from 2 June to 10 August 2020)>

Research Focus

\begin{tabular}{|c|c|}
\hline Components of Planning & Findings \\
\hline $\begin{array}{l}\text { Increasing } \\
\text { Competitiveness } \\
\text { through the }\end{array}$ & $\begin{array}{l}\text { 1. Encourage the participation of parents in } \\
\text { providing input and participate in trying to be a } \\
\text { connector for learning activities at home }\end{array}$ \\
\hline $\begin{array}{l}\text { Participation of } \\
\text { stakeholders at } \\
\text { SD Negeri } 1\end{array}$ & $\begin{array}{l}\text { 2. Receiving suggestions and input from the } \\
\text { community regarding efforts to improve the } \\
\text { quality of education }\end{array}$ \\
\hline
\end{tabular}

Implementation of the Principal's Strategy in an Effort to Improve the Competitiveness of SD Negeri 1 Supat

Supat, Babat

Supat District

Increasing

Competitiveness

Through planting the

character values of SD

Negeri 1 Supat, Babat

Supat District.

Increasing

Competitiveness through

Teaching Quality of SD

Negeri 1 Supat Teachers

Increasing

Competitiveness through

the creation of an

environment conducive

to teaching and learning process
Planting character values and optimizing extracurricular activities. The quality of educators and education personnel is also a concern of school principals to support process quality improvement.

1. Some teachers who were recommended to attend seminars, trainings and workshops by the school also held their own training activities

2. Supervise the teaching and learning process, supervise education personnel, and supervise infrastructure, with the aim of monitoring the performance of teachers and education personnel and the condition of students

1. Fostering commitment in implementing learning activities

2. Fostering the willingness of all school members to improve quality in a sustainable manner

3. Fostering the participation of school members in creating a safe and orderly environment

4. Creating solidarity and developing good communication

5. Foster high performance expectations 


\section{Obstacles in Increasing Competitiveness of SD Negeri 1 Supat}

Based on the results of data collection carried out by researchers, it can be argued that the obstacles faced in an effort to increase competitiveness in the quality aspects of learning at SD Negeri 1 Supat based on the results of data collection conducted by researchers, it can be argued that the obstacles faced by the principal improve the quality of learning at SD Negeri 1 Supat, in the aspect of planning, there was a lack of information received by the principal regarding the needs of SD Negeri 1 Supat teachers. Teachers were not very open when interviewed by the principal and the team appointed by the school principal to help plan the teaching ability improvement of SD Negeri 1 Supat. This was an obstacle for the principal of SD Negeri 1 Supat from arranging activities to increase the teaching ability of teachers. Practical only from the results of observations and the previous year's work plan were used by the principal as a reference in developing a program to increase the teaching ability of SD Negeri 1 Supat teachers. This is quite an obstacle in achieving the maximum development process.

Obstacles in the implementation of improving the quality of learning carried out by the principal of SD Negeri 1 Supat included the limited ability of some SD Negeri 1 Supat teachers especially in carrying out activities to increase the teaching ability of teachers. This was an obstacle where the coaching process takes a long time. One example was where some teachers had not been able to operate computers and access data via the internet. Related to efforts to improve the academic qualifications of SD Negeri 1 Supat teachers, there were obstacles where some teachers are not ready financially to continue their education to the next level because some teachers are still not certified and who are still honorary status. Another obstacle in the implementation of improving the teaching ability of SD Negeri 1 Supat teachers was the financial limitations of the school where the school does not collect committee money, so it practically only relies on BOS funds for school operations. Therefore, the principal was very selective in choosing what activities were more urgent to carry out and according to the needs of the teachers of SD Negeri 1 Supat.

which was carried out in SD Negeri 1 Supat, Babat Supat District; and 3) implementing the strategy set by the school.

In its implementation, the principal referred to the strengths possessed by SD Negeri 1 Supat which could be patterned into three major parts, namely having strength in the factors of facilities and infrastructure (buildings, multi-media facilities and student factors (an increase in the number of students enrolling at state schools). in each year, and the school's own factors that oversee the existence of multimedia-based learning compared to other schools around Ngablak sub-district.

The results of the research at SD Negeri 1 Supat were that the efforts of teachers and school principals to improve school competitiveness by implementing MPMBS had been carried out properly by carrying out the steps: 1) planning implementation (situation analysis, formulating objectives, SWOT analysis and alternatives solution to problem); 2) improving the quality of education by compiling and implementing programs; 3) implementation of monitoring and evaluation which was carried out continuously.

The strategy used by the school principal as an effort to improve the quality and competitiveness of other education was to make the school committee more effective and reform school organizations, develop the 2013 curriculum (K13), increase the professionalism of human resources (educators), fulfill the facilities and infrastructure, implement various learning programs, increase the hours of lessons with tutoring at the time after class ends.

The impact of the MPMBS on student achievement was quite good with the increase in academic and nonacademic achievement. Meanwhile, the impact of MPMBS on people's interest at schools was increasing, this was because the school always included committees in the implementation of education, the performance of effective public relations management in addition to the factors of good buildings, professional teachers and quality religious education. And the impact on teachers, with the implementation of MPMBS, SD Negeri 1 Supat teachers felt proud of the school. This was more due to: better school management, school cooperation and coherent committees, student achievement is increasing.

In this case, the strategy for improving the quality and competitiveness of SD Negeri 1 Supat could be analyzed through several things. The formulation of a strategy to increase the competitiveness of SD Negeri 1 Supat consists of several stages, namely: first, analysis of the Internal and External Environment. Second, the results of the analysis of the external environment were a number of opportunities that must be exploited and threats that must be prevented or avoided. Third, internal environmental analysis consisted of determining realistic perceptions of all the strengths and weaknesses of SD Negeri 1 Supat Grabag. Therefore, this school must take advantage of its strengths optimally and try to overcome its weaknesses in order to avoid losses in both time and budget. 
In responding to all kinds of changes and challenges of globalization, it can be said that SD Negeri 1 Supat has the courage to continue to move forward to catch up with it. Efforts to increase the competitiveness of their schools were also carried out, such as efforts to design them to become superior schools even though one of the inputs was that students were aware of their lack of quality by all residents of SD Negeri 1 Supat. Because of this, tutoring (additional hours of lessons) is held not only for exams.

Emphasis on the objectivity of the strategy to improve the quality of SD Negeri 1 Supat was very important for the implementation of the strategy. Efforts to increase the competitiveness of schools were arranged not on the basis of the personal will of the principal, but rather a collective will of all school members to accommodate public needs based on objectivity, scientific and systematic principles. The aim is the creation of a school management system and strategy that was undoubtedly and able to improve the quality that was competitive and profitable.

After obtaining an overview of the internal and external environment it faces, SD Negeri 1 Supat knew the basic conditions of the institution. So in determining strategies and efforts, it is necessary to pay attention to various things, including the ability of human resources (such as teachers, school principals, and employees) and budget. The steps for formulating a strategy in school management start from establishing a complete school vision and mission by involving the community and school stakeholders, conducting school assessments to respond to changes, and determining the direction of school recommendations to achieve predetermined goals and targets.

Based on the description above, it can be seen that in addition to the school's efforts to continuously improve the quality and competitiveness of its education, it turns out that the school also continues to strive to maintain every achievement it has achieved. Therefore, in this study it was found that the efforts of the principal of SD Negeri 1 Supat in increasing this competitiveness, in the end resulted in six school resources that have high carrying capacity which have been proven to provide success for schools in implementing efforts to improve quality and school competitiveness, namely : there was a continuous effort to increase the professionalism of the workforce consisting of teachers and employees, improve school management and administration with strong and visionary leadership as well as solid team work, increase the availability of learning resources, increase the success of curriculum implementation, increase the availability of procurement and maintenance of infrastructure, and increasing school accountability.

Thus it can be argued that efforts to improve the quality and competitiveness of schools can be carried out by applying the concept of Integrated Quality Management (PMT) or Total Quality Management (TQM). $\mathrm{PMT} / \mathrm{TQM}$ is an approach in running a business unit to optimize organizational competitiveness through continuous improvement initiatives of products, services, people, work processes, and the environment. [12] TQM is an integrated management philosophy and set of practice that emphasizes, among other things, continuous improvement, meeting customer's requirements, reducing rework, long-range thinking, increased employee involvement and team work, process red, competitive benchmarking, team-based problem solving, constant measurement of results, and closers relationships with suppliers. The opinion above emphasizes that PMT / TQM is an effort for continuous improvement in order to meet customer needs, both in goods and services. This means that organizations must be able to implement a culture change mechanism, from traditional culture to quality culture. The changes include four focus components, namely: plan, organize, control, communication. [12] In this case, the leadership of the principal has a determining role as a strength or authority (power) in gathering and mobilizing all resources in cooperation with the wider educational community, as well as to obtain various support for various information. institutions and political support from all levels of the education apparatus [15].

School-Based Quality Improvement Management (MPMBS) is a form of decentralization of education chosen with the aim of making schools independent and improving school quality and competitiveness. This policy is implemented by applying transparent management and by involving parties with an interest in education. In its implementation, the MPMBS policy has a different strategy in each school because MPMBS applies an idiographic approach (allowing for various ways of implementing it).

Then the research results from [2] that the strategy of the head of SMK Negeri 2 Bukittinggi in implementing the National Education Standards (SNP) was different according to each standard. In implementing content standards, a curriculum development team was formed. In implementing the process standards, Information and Technology (IT) based learning was carried out. In implementing graduate competency standards by increasing academic achievement. In implementing standards for educators and educational personnel by increasing the competence of educators and educational staff through training, and the like. In implementing standard facilities and infrastructure with planning, procurement, maintenance and inventory of school facilities and infrastructure. In implementing management standards by compiling School 
Work Plans (RKS) and School Budget Activity Plans (RKAS), formulating and disseminating the school's vision and mission.

Based on the results of research by [16] which stated that 1) the principal had made efforts to improve the quality of education at the 18 Tungkal Ilir Public Elementary School; 2) the principal had tried to solve the problems or obstacles that exist in the school so that the quality of education at the 18 Tungkal Ilir Elementary School could be improved. This was evident from the increase in the accreditation status of the predicate obtained in 2009 with a predicate "B" with a value of 76 . In 2015 efforts were made to improve the quality of education at 18 Tungkal Ilir Elementary School by evaluating deficiencies in improving the quality of education, so that there were an increase in several parts, including an increase in the professionalism of educators, this was done by sending teachers to take part in education and training, attending seminars and sending teachers to take part in other activities that increase teachers' insight in teaching, add to existing infrastructure, including increasing local learning from three classrooms to six classes, the library room was previously combined with an office, now it has its own library room.

\section{Conclusions}

From the results of research and discussion, the following conclusions can be drawn: 1) Principal's strategy to improve competitiveness in SD Negeri 1 Supat, Babat Supat District were: 1) plan a program to improve the quality and competitiveness of schools, both in the short and long term; 2) determine the program that had been planned in the form of an activity instrument which was carried out at SD Negeri 1 Supat, Babat Supat District; and 3) implementing the strategy set by the school. The implementation of the strategy for increasing the competitiveness of SD Negeri 1 Supat babat supat were: 1) increasing competitiveness through increasing stakeholder participation, including teachers, education staff and the community; 2) increasing competitiveness through the quality of learning; Increase competitiveness through a conducive school climat. 2) Constraints faced in efforts to increase competitiveness lie in efforts to improve the quality of learning at SD. 3) Solutions to some of the obstacles faced in increasing competitiveness through the quality of teaching at SD Negeri 1 Supat, among others were: 1) carrying out continuous coaching to increase the experience and knowledge of teachers; 2) supervising the teacher as well as evaluate and provide direction for improvement. Provide training and assignments to improve teachers' skills; 3 ) assignments in various activities both at school and outside of school as well as providing opportunities for teachers to interact and communicate with many parties; and 4) capacity building activities carried out through sending training participants, workshops, socialization, training, and KKG activities.

\section{References}

Sudarsana, I. K. (2016). Peningkatan mutu pendidikan luar sekolah dalam upayapembangunan sumber daya manusia. Jurnal Penjaminan Mutu, 1(1), 1-14.

Effendy, O. U. (2011). Ilmu Komunikasi: Teori dan Prakteknya. Bandung : Remaja Rosdakarya.

Dessel, A. (2010). Prejudice in schools: Promotion of an inclusive culture and climate. Education and Urban Society, 42(4), 407-429.

Hidayat, R. (2013). Pengaruh manajemen strategik dan biaya pendidikan terhadap daya saing sekolah di sekolah dasar negeri se-Kecamatan Mangkubumi Kota Tasikmalaya. Administrasi Pendidikan: Jurnal Ilmiah Mahasiswa Pascasarjana, 1(2), 187-192.

Usman, H. (2012). Manajemen. Teori, Praktik, dan Riset Pendidikan. Jakarta: Bumi Aksara.

Fitrah, M. (2017). Peran kepala sekolah dalam meningkatkan mutu pendidikan. Jurnal Penjaminan Mutu, 3(1), $31-42$.

Mulyasa. (2011). Manajemen Berbasis Sekolah, Konsep, strategi dan Implementasi. Bandung: PT Remaja Rosdakarya.

Kadir, S. R. (2019). Strategi Kepemimpinan Kepala Sekolah Dalam Meningkatkan Daya Saing Sekolah Di SMA Negeri 5 Gorontalo. Skripsi, 1(131414013).

Umayah, S. (2015). Upaya Guru dan Kepala Sekolah dalam Meningkatkan Daya Saing Sekolah. MUDARRISA: Jurnal Kajian Pendidikan Islam, 7(2), 259-288.

Koentjaraningrat. (2013). Metode-metode Penelitian Masyarakat. Jakarta: PT. Gramedia Pustaka Utama.

Miles and Huberman, (2013). Analisis Data Kualitatif Terjemahan oleh Tjetjeb Rohendi Rohandi. Jakarta : Universitas Indonesia.

Danim, S. (2012). Visi Baru Manajemen Sekolah ; Dari Unit Birokrasi ke. Lembaga Akademik. Jakarta : Bumu Aksara 
Sriwahyuni, E., Kristiawan, M., \& Wachidi, W. (2019). Strategi Kepala Sekolah Dalam Mengimplementasikan Standar Nasional Pendidikan (SNP) Pada SMK Negeri 2 Bukittinggi. JMKSP (Jurnal Manajemen, Kepemimpinan, dan Supervisi Pendidikan), 4(1), 21-33.

Hartini, H., Harapan, E., \& Wardiah, D. (2020). Upaya Kepala Sekolah dalam Meningkatkan Mutu Pendidikan Sekolah Dasar. Jurnal Al Qiyam, 1(1), 160-172.

Wahjosumidjo. (2013). Kepemimpinan Kepala Sekolah. Jakarta: PT Raja Grafindo Persada

Emzir. (2010). Metodologi Penelitian Pendidikan:Kuantitatif dan Kualitatif. Jakarta: Rajawali Pers. 